DOI: https://doi.org/10.32839/2304-5809/2020-12-88-53

УДК 613.2:616.89:725.511(477+061.1ec)

Чорна В.В.

Вінницький національний медичний університет імені М.I. Пирогова

Махнюк B.M.

Державна установа «Інститут громадського здоров'я імені О.М. Марзеєва Національної академії медичних наук України»

Хлестова С.С., Гуменюк Н.I. Вінницький національний медичний університет імені М.I. Пирогова

\title{
ПОРІВНЯЛЬНИЙ АНАЛІЗ ОРГАНІЗАЦІЇ ЛІКУВАЛЬНОГО ХАРЧУВАННЯ В ПСИХІАТРИЧНИХ ЛІКАРНЯХ УКРАЇНИ ТА КРАЇН СС
}

\begin{abstract}
Анотація. В статті висвітлено основні проблеми лікувального харчування в Україні та в країнах ЄС, узагальнені положення міжнародних стратегій ВООЗ щодо харчування населення та забезпечення раціонального, збалансованого харчування психічно хворих. Обгрунтовано поняття лікувальне харчування, як систему організації харчування, яка включає лікувальні і профілактичні заходи під час лікування хворого в стаціонарі з урахуванням характеру основного захворювання, ступеню важкості хвороби, показань та протипоказань. Дана характеристика проблемам організації та дотриманню норм лікувального харчування в закладах охорони здоров'я, які існують у зв'язку з постійним недофінансуванням цієї сфери. Виявлено проблеми невідповідних належних матеріально-технічних та санітарно-гігіенічних умов, психологічного комфорту, які вимагають певної корекції та повна відсутність штатних фрахівців-нутриціологів. Проведено аналіз показників індексу маси тіла психічно хворих які перебували на стаціонарному лікуванні. Проаналізовано результати соціологічного дослідження щодо витрат грошей родичів хворих 3 психічними захворюваннями на харчування їх, коли вони перебувають на стаціонарному лікуванні в закладах охорони здоров'я України. Для опитування родичів психічно хворих було використано спеціально розроблена анкета: «Спосіб визначення особистої думки родичів паціента про оплату медичної допомоги в психіатричному стаціонарі» визнано раціоналізаторською від 16.01 .2020 р. та зареєстровано в журналі реєстрації раціоналізаторських пропозицій ВНМУ ім. М.I. Пирогова за № 3. Обгрунтовано результати опитування родичів хворих з психічними розладами щодо частоти проходження стаціонарного лікування, висвітлено порівняльну картину видачі та різноманітності їжі для психічно хворих, які перебувають у лікувальному закладі України та країн ЄС. Результати анкетування оброблені за допомогою ліцензійного стандартизованого пакету «Statistica $6.1 »$. У роботі використовувалися аналіз вітчизняних та зарубіжних наукових джерел, бібліосемантичний, аналітичний та статистичний методи досліджень.
\end{abstract}

Ключові слова: здорове харчування, психічне здоров'я, психічно хворі, фрахівці-нутриціологи, біопсихосоціальне лікування.

Chorna Valentyna National Pirogov Memorial Medical University Makhniuk Valentyna State Institution "O.M. Marzieiev Institute for Public Health" of the National Academy of Medical Sciences of Ukraine Khliestova Svitlana, Humeniuk Nataliia National Pirogov Memorial Medical University

\section{COMPARATIVE ANALYSIS OF THE ORGANIZATION OF MEDICAL NUTRITION IN PSYCHIATRIC HOSPITALS OF UKRAINE AND EU COUNTRIES}

Summary. The article highlights the main problems of medical nutrition in Ukraine and the EU, summarizes the provisions of WHO international strategies for nourishment, and ensuring a rational, balanced diet for the mentally ill. The concept of therapeutic nutrition has substantiating as a system of nutrition organization, which includes curative and preventive measures during the treatment of the patient in the hospital, taking into account the nature of the underlying disease, the severity of the illness, indications, and contraindications. It describes the problems of organization and compliance with the norms of medical nutrition in health care facilities, which exist in connection with the constant underfunding of this area. Tasks of inadequate proper logistical and sanitary-hygienic conditions, psychological comfort, which require some correction, and the complete absence of full-time nutritionists have been identifying. The analysis of the body mass index of the mentally ill who remain in hospital. The results of a sociological study on the expenditure of money of parental patients with mental illness on their nutrition when they resume inpatient treatment in health care facilities of Ukraine are analyzed. A specially developed questionnaire has been using to interview the relatives of the mentally ill: "The method of determining the personal opinion of the patient's relatives about the payment of medical care in a psychiatric hospital" were recognizing as an innovation from 16.01.2020. And register in the journal of registration of innovation proposals of VNMU. MI Pirogov for № 3. The results of the survey of relatives of patients with mental disorders on the frequency of inpatient treatment have been substantiating, the comparative picture of the distribution and variety of food for mentally ill patients in a medical institution of Ukraine and EU countries has been highlighting. The results of the questionnaire were processed using the licensed standardized package "Statistica 6.1". The analysis of domestic and foreign scientific sources, biblio-semantic, analytical, and statistical research methods were applying in this work.

Keywords: healthy nutrition, mental health, mentally ill, nutritionists, biopsychosocial treatment.

(C) Чорна В.В., Махнюк В.М., Хлестова С.С., Гуменюк Н.І., 2020 
$\Pi$ остановка проблеми. Один із головних чинників здоров'я людини є харчування. Нераціональне, не збалансоване харчування впливає на показник DALY (Disability-Adjusted Life Year - це кількість років здорового життя, втрачених в результаті хвороби або смерті, який становив $16 \%$ серед дорослих усього світу за останні роки, а це 255 мільйонів років втрачено здорового життя внаслідок поганого харчування та багатьох фракторів $[1 ; 2]$.

Психічне здоров'я населення залежить від безпеки та якості харчових продуктів, і тому одним iз пріоритетних завдань ВООЗ $є$ якісне харчування в усьому світі. ВОО3, ООН на міжнародних конференціях розглядають глобальне питання в усьому світі для збереження та зміцнення генофонду сучасного суспільства щодо якісного, збалансованого харчування, боротьби 3 голодуванням в країнах з низьким рівнем життя.

ВОО3 у 2000 році розробила Глобальну стратегію запобігання неінфекційним захворюванням, які безпосередньо залежать від здорового способу життя, фрізичної активісті та раціонального, збалансованого харчування. ВООЗ не тільки розробляє заходи та ініціюе щодо протидії неінфекційних хвороб, але і пропонуе на регіональному рівні кожній державі розробляти нову політику щодо заходів направлених на зменшення дії головних чинників як нездорове харчування, не дотримання здорового способу життя, малорухливий спосіб життя, зловживання алкоголю та куріння, які призводять до збільшення неінфекційних хвороб та зменшують кількість років здорового життя [1-3]. Одніеї із стратегії ВООЗ щодо попередження неінфекційних захворювань у Свропейських країнах прийнято програму CINDI (Countrywide Integrated Noncommunicable Disease Intervention - Загальнонащіональна програма інтегрованої профрілактики неінфекційних захворювань), якою передбачено зменшення неінфекційних захворювань, які пов'язані зі способом життя, фрізичною активністю і раціональним, збалансованим харчуванням [4].

Декларацією Об'єднаних Націй 2000 року були затверджені та адаптовані заходи для кожної країни до 2015 року, щодо скорочення масштабів голоду населення світу та забезпечення якісним харчуванням, боротьби з інфекційними захворюваннями та туберкульозом, ВІЛ, малярією, які стали відомими як «Завдання розвитку тисячоліття». На 70-й сесії Генеральної Асамблеї ООН 2015 року були розроблені та затверджені нові напрямки розвитку «Перетворення нашого світу: порядок денний у сфері сталого розвитку до 2030 року», Україна як і всі країни-члени OOH прийняла цю стратегію з урахуванням специоріки національного розвитку [5; 6].

В Україні за статистичними даними ВООЗ рівень DALY (Disability-adjusted life уеar) роки втраченого життя 3 поправкою на інвалідність за 2017 рік становив 34 975,04 на 100 тис. населення, що в двічі вищий у порівнянні з країнами Західної Свропи. У структурі стандартизованих за віком втрат років життя (DALY) за 2017 рік в Україні 75,9\% припадає на втрати від неінфекційних захворювань. На сьогодні в Украйні є багато проблем у вирішенні продрілактичних заходів щодо неінфекційних захворювань, які пов'язані зі здоровим способом життя, незбалансованим, нераціональним харчуванням, як і незавершеною редрормою у галузі охорони здоров'я, відсутністю медичного страхування та єдиної електронної системи обміну медичною інформацією та інше [1-3].

Аналіз останніх досліджень і публікацій. За останніми даними ВООЗ проблема психічного здоров'я, а особливо депресії, тривожні розлади до 2030 року посядуть друге-трете місце серед найпоширеніших тягарів захворювань, які $є$ основним фрактором глобальної інвалідності у країнах 3 низьким і середнім рівнем доходу та в усьому світі [7]. У світі ці захворювання спостерігаються більше як у 300 мільйонів населення планети, із них 7\% становить населення жіночої статі та 4\% становить населення чоловічої статі. На лікування щороку держави витрачають біля 1 трлн. доларів і прикро, що у 50\% хворих спостерігається рецидив [8; 9]. За останніми науковими даними причини збільшення психічних захворювань $€$ нездорове, незбалансоване харчування.

Науковці всього світу вивчають великий вплив на психічне здоров'я зв'язку із споживанням висококалорійної та жирної їжі, а саме: червоного м'яса, транс-жирів, надмірне споживання цукру, солі, солодких та газованих напоїв, солодощів. За даними австрійських науковців 52,2\% жінок і 43,2\% чоловіків споживають менше необхідного для їх організму вітаміну $\mathrm{B}_{1}, 73 \%$ жінок і $58 \%$ чоловіків споживають фолієвої кислоти нижче рекомендованої добової дози (300 мкг/добу), які $\epsilon$ у фрруктах, овочах, горіхах, цільнозернових продуктах [10-12].

Результати багатьох вчених підкреслюють головну роль харчування у психіатричній допомозі для зменшення тривожних, депресивних, суїцидальних розладів. Вони пропонують використовувати біопсихосоціальне лікування, яке включає нутритивні втручання щодо профілактики та лікування психічних розладів як глобального тягаря хвороб XXI сторіччя [13-15].

В країнах СС постійно проводиться оцінка, перехресні аудити щодо якості, складу лікувального харчування в закладах охорони здоров'я. Так, наприклад, з 2006 по 2012 рр. проведено анкетування пацієнтів у 51 країні щодо перехресного аудиту лікарень 3 метою оцінки стану харчування, визначення загального стану здоров'я пащієнтів 3 погляду харчування. Всі пащієнти, які поступають у лікарню в країнах ЄС проходять перевірку харчування протягом 24-48 годин після прийому їх в стаціонар, а саме: визначення індексу маси тіла (IMT) хворого для вирішення питання щодо ознак недоїдання і прийняття рішення щодо методу харчування. В закладах охорони здоров'я Іспанії при поступленні хворого проводиться метод скринінгу харчових ризиків-2002 (NRS-2002) для визначення «дієтичного діагнозу», в який включено данні історії хвороби, фрізичного обстеження (IMT), біохімічні аналізи, фонкціональні тести [16; 17].

Біопсихосоціальний підхід лікування у лікарнях слугуе потребам здоров'я хворих і забезпечуе добробут під час перебування в стаціонарі. Лікувальне харчування у всіх закладах охорони здоров'я в европейських країнах покладено на медичних працівників, обов'язками яких $є$ розроб- 
ка, планування і контроль за складанням дієт, виконання норм для хворих з різною патологією, 3 різними методами годування (ентеральним або парентеральним). Процес приготування та збереження харчової цінності їжі, якості і безпечності харчових продуктів та її наслідки для здоров' я хворих знаходиться на особливому контролі у закладах охорони здоров'я в країнах ЄС будь якої фрорми як у державних, так і у приватних [18; 19].

Виділення не вирішених раніше частин загальної проблеми. На сьогодні в Україні нормативну базу щодо харчування хворих в лікарнях складають наступні регламентуючі документи: Закон України «Про безпечність та якість харчових продуктів» (від 2010 р. за № 2809-IV), Постанова Кабінету Міністрів України «Про норми харчування для осіб, хворих на туберкульоз та інфікованих мікобактеріями туберкульозу» (від 2001 р. за № 1752), Наказ Міністерства охорони здоров’я України «Про удосконалення організації лікувального харчування та роботи дієтологічної системи в Україні» (від 2013 р. № 931) та інші [20-22].

Не менш актуальним $є$ харчування в психіатричних лікарнях для хворих, які в залежності від стану хвороби повинні проходити лікування під час загострення хвороби в стаціонар на деякий час, а інколи на довготривалий період. Недофінансування психіатричних лікарень $є$ наслідком незбалансованим і недостатнім харчуванням психічно хворих i не дозволяє забезпечити здоровим харчуванням і ще більше загостряє психічне здоров'я пащієнтів. Лікувальний заклад охорони здоров'я відповідає не тільки за відновлення психічного стану, a i за адекватне лікувальне харчування.

Особливе занепокоєння при проведенні моніторингу трьох обласних психоневрологічних лікарень (Миколаївської, Полтавської, Херсонської) у 2015 рощі Українською Хельсінкською спілкою з прав людини викликало занепокоєння у нормах, які прийняті у новому Наказі Міністерства охорони здоров’я України «Про удосконалення організащї лікувального харчування та роботи дієтологічної системи в Україні» від 2013 р. № 931. Норми харчування на одного пацієнта в цьому документі суттєво зменшились. Так наприклад, на добову норму картоплі скоротили 3400 гр. на 200 гр, м'яса 3125 гр. на 50 гр., риби свіжомороженої 3100 гр. на 50 гр., масла вершкового 340 гр. на 10 гр., м’якого сиру з 70 гр. на 55 гр., сметани з 20 гр. на 15 гр., хліба з 350 гр. на 250 гр. Нажаль, в Наказі № 931 взагалі відсутні: сир твердий, хлібопекарські і кондитерські вироби, кисіль, джеми, повидло, дріжджі, відсутні крупи, крім пшеничної і ячмінної. Норми харчування у зазначеному документі поділенні на три групи (гіпотрофрія, нормотрофрія, гіпертрофрія), але це тільки на папері. Зі звіту фінансування на харчування у психоневрологічних лікарнях за 2015 рік зменшено у чотири рази в порівнянні 32014 роком. Хворі які перебувають на стаціонарному лікування не повинні групуватись біля «дієтичних столів» за ознакою IMT [22-24]. Але для таких хворих навпаки необхідно враховувати вплив лікарських препаратів, стан пацієнтів і термін перебування. Лікарські препарати в сучасній психіатрії призводять до побічних дій на процес травлення, зменшення шлункової секреції, вміст шлункового соку, соляної кислоти, а також антидепресанти можуть викликати нудоту, втому, сонливість або навпаки безсоння, сексуальні проблеми, а це мало враховується лікарями психіатричних лікарень. В лікувальних закладах для психічно хворих відсутні консультації 3 фахівцями-нутриціологами [25].

Мета статті. Головною метою ціеї роботи $є$ аналіз організації лікувального харчування в психіатричних лікарнях в Україні та в різних країнах ЄС для впровадження міжнародного досвіду в систему організації лікувального харчування хворих психіатричних закладів охорони здоров'я України.

Виклад основного матеріалу. Проведено аналіз IMT 132 осіб - психічно хворих пацієнтів Комунального некомерційного підприємства «Вінницька обласна клінічна психоневрологічна лікарня ім. акад. О.I. Ющенка Вінницької обласної Ради», із них - 48,5\% чоловіків та 51,5\% жінок, віком від 21 до 40 років - 25,8\%, від 41 до 60 років - 49,2\%, від 61 і старше $-25,0 \%$.

А також проведено опитування родичів психічно хворих пацієнтів щодо витрат грошей на медичні послуги, медичні препарати, на продукти для своїх родичів, які перебували на стаціонарному лікуванні. В опитуванні прийняли участь 92 особи, із них 29,3\% - чоловіків та $70,7 \%$ - жінок, віком до 20 років - 3,3\%, від 21 до 30 років - 9,8\%, від 31 до 40 років $-17,4 \%$, від 41 до 50 років - 33,7\% і старше 50 років $35,9 \%$. В опитуванні брали участь рідні хворих на психічні захворювання, які доводились пацієнтам чоловіками - 20,0\%, дружинами - 46,7\%, дітыми - 26,6\%, родичами - 6,7\%, із них мешкали спільно з хворими - 69,3\% і 30,7\% - окремо. Із загальної кількості опитуваних родичі хворих у 52,2\% випадків - працюють, у 29,3\% - пенсіонери, у 10,9\% - не працюють, у 7,6\% - навчаються.

Для опитування родичів психічно хворих було використано спеціально розроблена анкета: «Спосіб визначення особистої думки родичів пацієнта про оплату медичної допомоги в психіатричному стаціонарі» визнано раціоналізаторською від 16.01.2020p. та зареєстровано в журналі реєстраціі ращіоналізаторських пропозицій BНMУ ім. M.I. Пирогова за № 3 [26].

Результати анкетування оброблені за допомогою ліцензійного стандартизованого пакету «Statistica 6.1». Також у роботі використовувалися аналіз вітчизняних та зарубіжних наукових джерел, бібліосемантичний, аналітичний та статистичний методи досліджень.

Проведений аналіз щодо IMT 132 осіб - психічно хворих пацієнтів показав, що пацієнтів поділя-

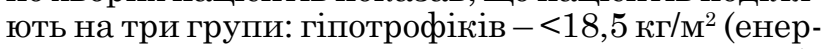
гетична цінність дієти на рівні 2400-2700 ккал),

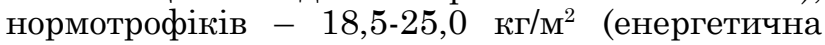
цінність дієти 2200-2400 ккал), гіпертрофіків $>25 \kappa \Gamma / \mathrm{M}^{2}$ (низькокалорійна дієта, енергетична цінність дієти становить 1800-2000 ккал) [22]. $\mathrm{Y}$ результаті аналізу даних IMT хворих встановлено, що до групи гіпотрофріків серед чоловіків складало - 6,2\%, серед жінок - 5,9\%; до групи нормотрофікв 3 групи чоловіків складало - 68,8\% i 67,6\% серед жінок; до групи гіпертрофріків чоловіків складало - 25,0\% і жінок - 26,5\%.

Проведений аналіз антропометричних показників показав (табл. 1), що у чоловіків хворих 
3 масою тіла, яка не перевищує за норму складала $65,2+8,5$, а у жінок 55,6+6,4, 3 масою тіла, яка перевищувала норму у чоловіків хворих складала $84,7+10,4$, а у жінок $83,8+24,2$. Із загальної групи гіпотрофріків $6,0 \%$, середня вага у чоловіків хворих складала $-41,5+14,3$, а у жінок хворих $41,2+3,9$, яким потрібно призначати дієти з енергетичною цінністю на рівні 2400-2700 ккал. Моніторинг едективної нутріціологічної підтримки для групи хворих з гіпотрофією повинен проводитись щоденний контроль за вагою, IMT. Для виявлення ознак дефіциту нутрієнтів, оцінки енергетичного балансу, білкового, ліпідного, вуглеводного, вітамінного, мінерального обміну згідно наказу № 931 повинен проводитися один раз на тиждень. В даному наказі заначено, що контроль за едективністю організації лікувального харчування, набором продуктів і страв, технологією приготування, енергетичною цінністю та хімічним складом проводить керівництво лікувального закладу охорони здоров'я. Але за даними моніторингу Української Гельсінської спілки прав людини, громадських організацій та підтримки МОЗ України за 2015 р. у обласних психоневрологічних лікарнях Миколаївської, Полтавської та Херсонської областей зазначено зменшення фінансування на харчування для хворих, тому з'являються сумніви щодо лікувального харчування в психоневрологічних закладах охорони здоров'я, які дотримувались чотирьох головних складових: адекватності енергетичних витрат, збалансованості за вмістом нутрієнтів, безпечності їжі, задоволеність від споживання їжі [22; 24]. В порівнянні з Свропейськими країнами, в яких постійно проводяться рандомізовані контрольні дослідження, які спрямовані на персоналізований підхід у харчуванні психічно хворих, на покращення стану здоров'я шляхом біопсихосоціального лікування [27-29].

За результатами опитування родичів з'ясувалось, що 1 раз на рік паціенти проходять лікування в стаціонарі від загальної кількості опитаних - 56\%, (3 них 69,2\% - чоловіки і 49,0\% жінки); 2 рази на рік - 40,0\% (із них $30,8 \%$ - чоловіки і 44,9\% - жінки), 3 рази на рік - 4,0\% (iз них тільки $6,1 \%$ - жінки).
Тривалість госпіталізації в середньому складає 22,5 днів (від 10 до 60 днів). За даними опитування ми спостерігаємо в 1,5 рази перебування чоловіків в стаціонарі більше ніж жінок за рік, але загострення психічних розладів частіше спостерігаються у 44,9\% жінок, які перебувають на стаціонарному лікуванні по два рази і $6,1 \%$ жінок по три рази на рік (див. рис. 1).

Під час перебування в стаціонарі за результатами опитування на запитання «Чи доводилося Вам оплачувати медичні послуги за рахунок власних коштів» встановлено, що респондентам доводилось оплачувати медичні послуги для своïх родичів-хворих із загальної кількості опитаних 36,0\% (з них 19,2\% - чоловіки і 44,9\% - жінки), частково доводилось оплачувати медичні послуги від загальної кількості опитаних 29,3\% (з них $42,3 \%$ - чоловіки і $22,4 \%$ - жінки), і $34,7 \%$ із загальної кількості опитаних відповіли, що не оплачували будь які послуги (з них $38,5 \%$ - чоловіки i $32,7 \%$ - жінки). Більшість витрачених грошей припадало на оплату за діагностичні послуги.

На запитання «Чи викликала оплата медичної допомоги проблеми у сімейному бюджеті» із опитаних респондентів відмічали великі проблеми у $26,7 \%$ (з них $15,4 \%$ - чоловіки і $32,7 \%$ жінки), незначні проблеми виникали при оплаті медичних послуг у 69,3\% (з них 76,9\% - чоловіки i 65,3 -жінки), i у 4,0\% респондентів жодних проблем не виникало у родин при оплаті за медичні послуги (з них 7,7\% - чоловіки і 2,0\% - жінки).

За результатами анкетування родичів психічно хворих на запитання «Вкажіть на які цілі витрачаєте гроші під час лікування родича» встановлено, що респонденти витрачають гроші на продукти, які приносять своїм родичам-хворим у стаціонар психоневрологічної лікарні, у 96\% випадків (з них 100\% - чоловіки і 93,9\% -жінки). В Україні за рахунок державного фрінансування на харчування одного хворого витрачається в середньому 17 грн. на добу. При цьому харчування хворих в лікарнях Республіки Польща за даними Вищої аудиторської служби, середньодобові витрати на харчування у контрольованих лікарнях за 2015-2017 рр. складали 9,55-17,99 злотих (71,14-134,03 грн.) [30; 31].

Антропометричні показники психічно хворих, які перебували

Таблиця 1 на стаціонарному лікуванні $(\mathrm{M}+\mathrm{m})$, щодо ваги, росту, IMT

\begin{tabular}{|c|c|c|c|c|c|c|}
\hline \multirow{4}{*}{$\begin{array}{c}\text { Tрофолоогічни } \\
\text { групи }\end{array}$} & \multicolumn{6}{|c|}{ Антропометричні показники } \\
\hline & \multicolumn{6}{|c|}{ Вага (кг) } \\
\hline & \multicolumn{3}{|c|}{ Чоловіки n=64 } & \multicolumn{3}{|c|}{ Жінки n=68 } \\
\hline & $\mathbf{M}+\mathbf{m}$ & $t$ & $\mathbf{p}$ & $\mathbf{M}+\mathbf{m}$ & $\mathbf{t}$ & p \\
\hline нормотрофіки & $65,2+8,5$ & 2,02 & 0,05 & $55,6+6,4$ & 2,02 & 0,05 \\
\hline гіпертрофіки & $84,7+10,4$ & 2,13 & 0,05 & $83,8+24,2$ & 2,11 & 0,05 \\
\hline \multirow[t]{2}{*}{ гипотрофіки } & $41,5+14,3$ & 3,18 & 0,05 & $41,2+3,9$ & 3,18 & 0,05 \\
\hline & \multicolumn{6}{|c|}{ Pict (см) } \\
\hline нормотрофіки & $172,0+0,09$ & 2,02 & 0,05 & $159+0,08$ & 2,02 & 0,05 \\
\hline гіпертрофіки & $175+0,07$ & 2,13 & 0,05 & $162+0,06$ & 2,11 & 0,05 \\
\hline \multirow[t]{2}{*}{ гипотрофіки } & $157+0,24$ & 3,18 & 0,05 & $158+0,06$ & 3,18 & 0,05 \\
\hline & \multicolumn{6}{|c|}{ IMT } \\
\hline нормотрофіки & $21,8+1,9$ & 2,02 & 0,05 & $21,9+1,7$ & 2,02 & 0,05 \\
\hline гіпертрофріки & $27,6+2,3$ & 2,13 & 0,05 & $32,4+8,6$ & 2,11 & 0,05 \\
\hline гипотрофріки & $16,3+1,9$ & 3,18 & 0,05 & $16,1+1,1$ & 3,18 & 0,05 \\
\hline
\end{tabular}




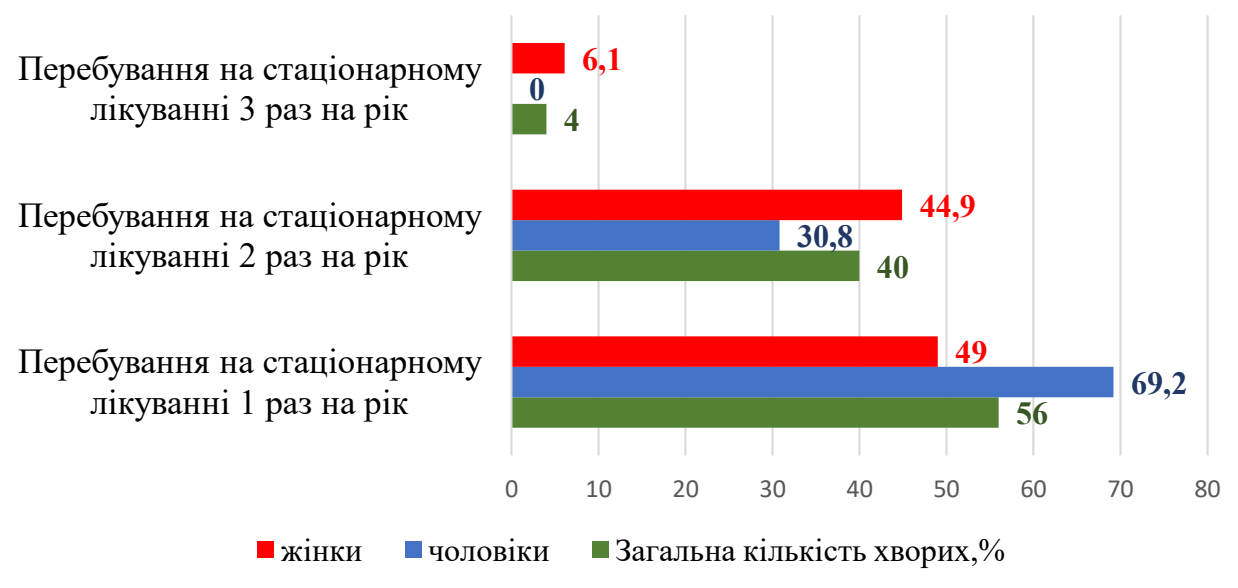

Рис. 1. Результати опитування родичів хворих з психічними розладами щодо частоти проходження стаціонарного лікування, (у \%)

Порівняльна картина видачі та різноманітності їжі для психічно хворих, які перебувають у лікувальному закладі України та Німеччини (див. рис. 2, 3).

Родичами хворих також витрачаються гроші на медичні препарати для лікування пацієнтів в стаціонарі, так відповіли 85,3\% респондентів від загальної кількості опитаних (з них 77,0\% чоловіки і 89,8\% - жінки), на засоби особистої гігієни витрачають гроші 81,3\% опитаних (3 них 80,8\% - чоловіки і 81,6\% - жінки).

За результатами опитування та проведеними розрахунками на одне відвідування родич-
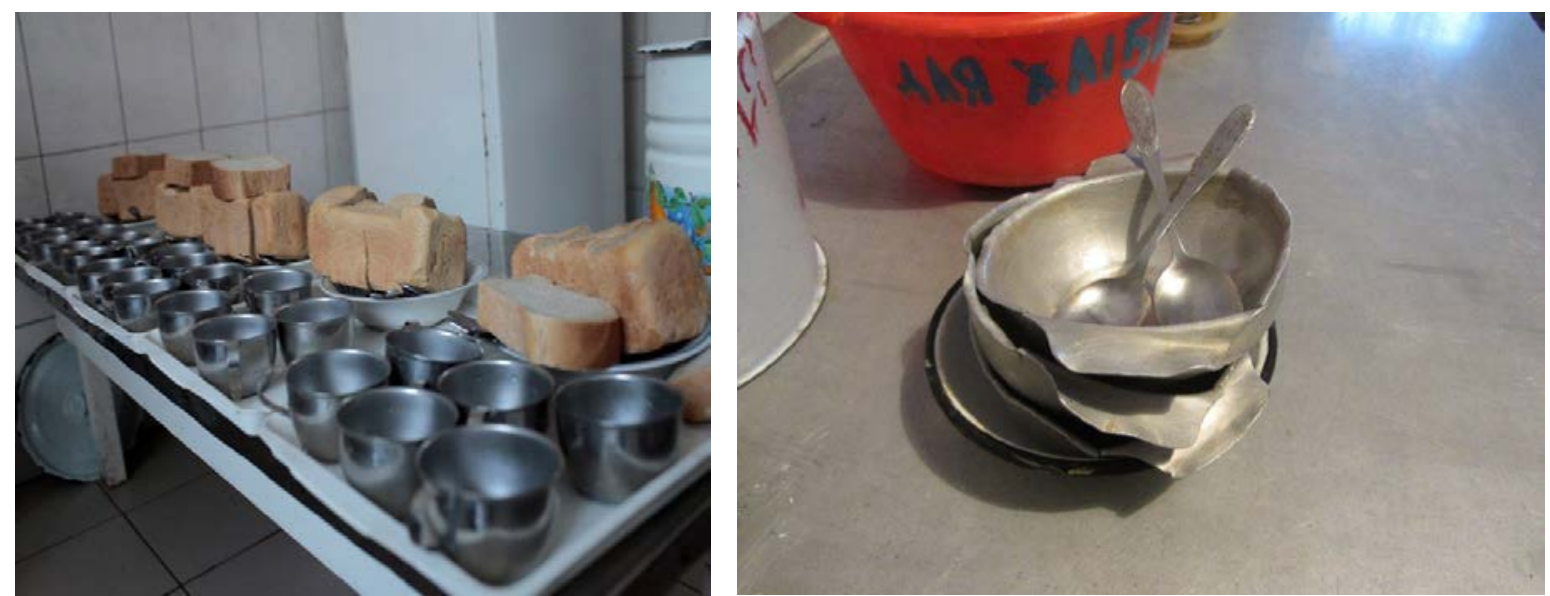

Рис. 2. Вигляд кімнати видачі їжі Обласної Вільшанської психіатричної лікарні (с. Вільшани, Хустський район Закарпатської області)
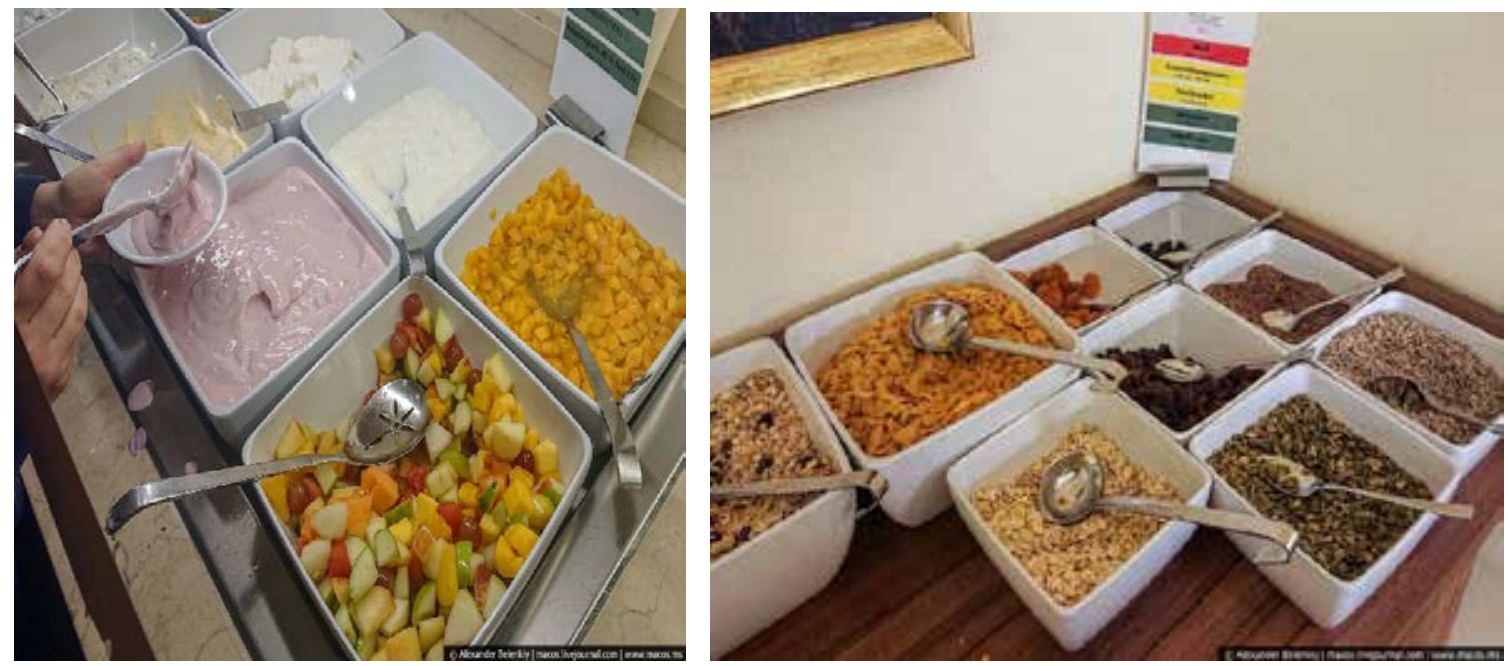

Рис. 3. Вигляд «шведського столу" в одній клініці Medical Park Berlin Humboldtmühle (Німеччина) 
Перелік відповідей родичів хворих психіатричній лікарні

Таблиця 2 щодо оцінки медичного обслуговування, (у \%)

\begin{tabular}{|c|c|c|c|}
\hline Заходи & $\begin{array}{c}\text { Питома вага } \\
\text { сімей }\end{array}$ & $\begin{array}{c}\text { Питома вага } \\
\text { родичі-чоловіки }\end{array}$ & $\begin{array}{l}\text { Питома вага } \\
\text { родичі-жінки }\end{array}$ \\
\hline висока вартість ліків & 92,0 & 80,8 & 98,0 \\
\hline слабке, застаріле оснащення стаціонару & 77,3 & 76,9 & 77,6 \\
\hline погані санітарно гігієнічни умови & 62,6 & 61,5 & 63,3 \\
\hline збільшення обсягу платної медичної допомоги & 60,0 & 61,5 & 59,2 \\
\hline зніження якості медичної допомоги & 37,3 & 42,3 & 34,7 \\
\hline $\begin{array}{l}\text { неуважне ставлення медичного персоналу(порушення } \\
\text { етики по відношенню до пацієнтів) }\end{array}$ & 34,7 & 34,6 & 34,7 \\
\hline сервісні послуги не на належному рівні & 29,3 & 38,5 & 24,5 \\
\hline недостатньо висока кваліфрікація медичного персоналу & 16,0 & 19,2 & 14,3 \\
\hline
\end{tabular}

жінка витрачає $337+189$ грн, родич-чоловік $330+172$ грн. $(\mathrm{r}=0,96, \mathrm{p}<0,00004)$.

Витрати на медичні послуги, медичні препарати для лікування, харчування, засоби особистої гігіени та інші потреби лягають на плечі рідних психічно хворих.

Блок відповідей запропонованих родичам паціентів психоневрологічної лікарні на питання «Що викликае у Вас сьогодні найбільшу тривогу в медичному обслуговуванні психіатричних лікарень?» дали наступні відповіді (табл. 2).

Зазначені результати вимагають створення належних матеріально-технічних та санітарно-гігіенічних умов, психологічного комфорту. Адміністрація психіатричних закладів охорони здоров'я повинна проводити роз'яснення медичному персоналу щодо відповідності до статті 49 Конституції України про надання безоплатної психіатричної допомоги, а не за гроші родичів хворих, систематично проводити ознайомлення персоналу лікарень із міжнародними стандартами дотримання прав пацієнтів та перевіряти виконання шляхом перехресних аудитів та анкетуванням для сприяння покращення внутрішньолікарнянного мікроклімату у закладах охорони здоров'я психоневрологічного напрямку [24]. Так, на прикладі Республіки Польща відповідно до За- кону «З охорони психічного здоров’я» («Ustawa о ochronie zdrowia psychicznego»), який діє упродовж 26 років (прийнятий 19.08.1994 року) паціент психоневрологічної лікарні має право на безкоштовні медичні послуги, ліки, санітарно-гігієнічні товари, харчування та інше [32].

Висновки і пропозиції. 1. Вважаемо за необхідне імплементувати европейські закони, вимоги щодо покращення якості та збільшення фінансування на харчування одного хворого на добу у психіатричних закладах охорони здоров'я України та розробити доповнення до «Наказу Міністерства охорони здоров'я України від 29.10.2013 р. № 931 «Про удосконалення організації лікувального харчування та роботи діетологічної системи в Україні».

2. МОЗ України пропонуемо визначити аудиторську службу щодо перехресних аудитів у лікарень 3 метою оцінки стану харчування, виконання норм для хворих, а також введення в штат психоневрологічних лікарень фахівця-нутриціолога як в країнах $\mathrm{CC}$.

3. Харчування в психіатричних лікарнях повинні дотримуватись чотирьох головних складових: адекватності енергетичних витрат, збалансованості за вмістом нутріентів, безпечності їжі, задоволеність від споживання їжі.

\section{Список літератури:}

1. Показники захворюваності і поширеності та сучасні погляди на профілактику хвороб. В.В. Чорна, С.С. Хлестова, Н.І. Гуменюк [та ін.] Вісник Вінницького національного медичного університету. 2020. Т. 24(1). C. 158-164. https://doi.org/10.31393/reports-vnmedical-2020-24(1)-31

2. Chorna V.V., Makhniuk V., Gumeniuk N., \& Tomashevskyi A. (2020) Comparative analysis of morbidity indicators among the population of the eu and Ukraine under conditions of stressed load of the Anti-nerrorist operations and psychoprophylaxis measures. Georgian medical al news, 5(302):147-154.

3. Чорна В.В. Детермінація психічного здоров'я населення України та країн ЄС. Довкілля та здоров'я. 2020. № 2(95). C. 47-53. https://doi.org/10.32402/dovkil2020.02.047

4. Стратегия предупреждения хронических заболеваний в Европе. Основное внимание действиям общества по укреплению общественного здоровья. Видение стратегии с позиций CINDI електроний ресурс ЕРБ ВОЗ. Всемирная организация здравоохранения Европейское региональное бюро. URL:http://www.euro.who.int/_ data/assets/pdf_file/0011/134849/E83057R.pdf

5. 55/2. United Nations Millennium Declaration/Resolution adopted by the General Assembly [without reference to a Mail Committee (A/55/L.2); $8^{\text {th }}$ plenary meeting, 8 September 2000] URL: Unted Nations. URL:http:www.un.org/, Цели в области развития, поставленные в Декларации тисячелетия. Електроний ресурс (18 september 2000), Millennium Development Goals (MDGs). URL: http://www.un.org/millenniumgoals/index.shtml

6. Аналіз державних стратегічних документів України щодо врахування адаптованих для України Цілей Сталого Розвитку до 2030 року : Аналітична доповідь. Київ : Інститут суспільного-економічних досліджень, 2017. 84 с.

7. Психічне здоров'я на перехідному етапі: результати оцінювання та рекомендації для інтеграції охорони психічного здоров'я в систему первинної медичної допомоги та громадські платформи в Україні. Міжнародний медичний корпус за підтримки групи Світового Банку. World Bank Group. URL: documents. worldbank.org/120767-Ukrainian-PUBLIC-mental-health-UA/ipz.org.ua/uploads/2018/01/MH-report-for_ INTERNET_All_ua 
8. Camille Lassale, G. David Batty, Amaria Baghdaali \& Tasnime Akbaraly. Healthy dietary indices and risk of depressive outcomes: a systematic review and meta-analysis of observational studies. Mol Psychiatry. 2019. 24(7):965-986. doi: https://doi.org/10.1038/s41380-018-0237-8

9. Roger A.H. Adan, Eline M. van der Beek, Jan K. Buitelaar \& Suzanne L. Dickson. Nutritional psychiatry: Towards improving mental health by what you eat. European Neuropsychopharmacology. 2019.29.12.1321-1332. https://doi.org/10.1016/j.evroneuro.2019.10.011

10. Lauren Owen, Bernard Corfe. The role of diet and nutrition on mental health and wellbeing. Proceedings of the Nutrition Society. 2017. 76(4):425-426. doi: https://doi.org/10.1017/SOO29665117001057

11. Morkl S., Wagner-Skacel J., Lahousen T. \& Reininghaus E.Z. The role of nutrition and the gut-brain axis in psychiatry: a review of the literature. Neuropsychobilogy. 2020.79:80-88. https://doi.org/10.1159/000492834

12. Joseph Firth, Brendon Stubbs, Scott B Teasdale \&Jerome Sarris. Diet as hot topic in psychiatry: a population-scale study of nutritional intake and inflammatory potential in severe mental illness. World Psychiatry.2018.17(3):365-367. doi: https://doi.org/10.1002/wps.20571

13. Moufidath Adjibade, Cedric Lemogne, Chantal Julia \& Emmanuelle Kesse-Guyot. Prospective association between adherence to dietary recommendations and incident depressive symptoms in the French NutriNet-Santé cohort. British Journal of Nutrition.2018,120(3):290-300. doi: https://doi.org/10.1017/S0007114518000910

14. Miquel Rosa, Elisabeth Kohls, Margalida Gili \& Brenda W Penninx. Prevention of depression through nutritional strategies in high-risk persons: rationale and design of the MooDFOOD prevention trial. BMC Psychiatry. 2016,16:192. doi: https://doi.org/10.1186/s12888-016-0900-z

15. Wolfgang Marx, Genevieve Moseley, Michael Berk, Felice Jacka. Nutritional psychiatry: the present state of the evidence. Proceedings of the Nutrition Society. 2017. 76(4):427-436. doi: https://doi.org/10.1017/SOO29665117002026

16. Karin Schindler, Sigrid Kosak, Tatjana Schütz \& Michael Hiesmayr. [nutritionDay- an annual cross-sectional audit of nutrition in healthcare]. Ther Umsch. 2014, 71(3):127-33. doi: https://doi.org/10.1024/0040-5930/a000493

17. Rocío Campos del Portillo, Samara Palma MiIla, Natalia García Váquez \& Carmen Gómez-Candela . Assessment of nutritional status in the healthcare setting in Spain. Nutr Hosp. 2015 Feb 26;31 Suppl 3:196-208. doi: https://doi.org/10.3305/nh.2015.31.sup3.8767

18. Teresa Valero Gaspar, Jose Manuel Avila Torres, Gregorio Valera-Moreiras. Healthy gastronomy education: challenges and opportunities in the institutional food service. Nutricion Hospitalaria 2018, 35(Spec No4):56-60. doi: https://doi.org/10.20960/nh.2127

19. Maria Garriga Garcia, Arantza De Las Heras de la Hera. Hospital feeding and healthy gastronomy. Review Nutr Hosp. 2018, 35(Spec No4):140-145. doi: https://doi.org/10.20960/nh.2140

20. Закон України «Про безпечність та якість харчових продуктів» від 2010 р. URL: https://www.president.gov.ua/documents/2809-iv-3236 (дата звернення: 06.09.2005).

21. Постанова Кабінету Міністрів України «Про норми харчування для осіб, хворих на туберкульоз та інфікованих мікобактеріями туберкульозу» від 2001 р. за № 1752. URL: https://zakon.rada.gov.ua/laws/show/17522001-\%D0\%BF\#Text (дата звернення: 23.11.2012).

22. Наказ Міністерства охорони здоров’я України «Про удосконалення організації лікувального харчування та роботи дієтологічної системи в Україні» від 2013 р. № 931. URL: https://zakon.rada.gov.ua/laws/show/z220513\#Text (дата звернення: 29.10.2013).

23. Imerelli R.E., Kazachinskaya K.P., Moisa B.S. \& Shum, S.S. (2016) Rights of persons with mental health problems. Respect for human rights in psychiatric hospitals. Analytical report of the Ukrainian Helsinki Human Rights Union. Ukrainian Helsinki Human Rights Union. K.: KIT, 2016. 34 p.

24. Імереллі Р.Е., Казачинська К.П., Мойса Б.С., Шум С.С. Права осіб із проблемами психічного здоров'я. Дотримання прав людини у психіатричних лікарнях : Аналітичний звіт Української Гельсінської спілки 3 прав людини. Українська Гельсінська спілка з прав людини. К.: КИТ, 2016. 34 с.

25. Qingyi Huang, Huan Liu, Katsuhiko Suzuki, Sihui Ma, Chunhong Liu. Linking what we eat to our mood: a review of diet, dietary antioxidants, and depression. Antiioxidants (Basel). 2019,8(9):376. doi: https://doi.org/10.3390/antiox8090376

26. Свідоцтво на раціоналізаторську пропозицію від 16.01.2020p. № 3 «Спосіб визначення особистої думки родичів паціента про оплату медичної допомоги в психіатричному стаціонарі» / Чорна В.В., Махнюк В.М., Очеретяна Г.В., Хлестова С.С., Гуменюк Н.I.

27. Jerome Sarris, Alan C LOGAN, Nasnime N Akbaraly \&Felice N Jacka. Nutritional medicine as mainstream in psychiatry. Review Lancet Psychiatry. 2015. 2(3):271-274. doi: https://doi.org/10.1016/S2215-0366(14)00051-0

28. Jerome Sarris. Nutritional psychiatry: from concept to the clinic. Review Drugs. 2019.79(9):929-934. doi: https://doi.org/10.1007/s40265-019-01134-9

29. Roger A.H. Adan, Eline M. van der Beek, Jan K. Buitelaar \& Suzanne L. Dickson. Nutritional psychiatry: towards improving mental health by what you eat. European Neuropsychopharmacology. 2019. 29 (12):1321-1332. doi: https://doi.org/10.1016/j.euroneuro.2019.10.011

30. Aldona Głwacky. PROBLEMATYKA I ZASADY ŻYWIENIA PACJENTÓW HOSPITALIZOWANYCH W ODDZIAEACH PSYCHIATRYCZNYCH. KRAKOWSKA AKADEMIA im. Andrzeja Frycza Modrzewskiego. 2018. 38p.

31. Закаль Ю. Про охорону здоров'я в Республіці Польща // Вестник Ассоциации психиатров Украины. 2011. № 2. URL: http://www.mif-ua.com/archive/article/27208

32. «Ustawa o ochronie zdrowia psychicznego» 19 sierpnia 1994 r. «Закон з охороною психічного здоров'я» Республіки Польща 19.08.1994 p.

33. Law of Ukraine "On food safety and quality" of 2010 for № 2809-IV (accessed 06.09.2005).

\section{References:}

1. Incidence and prevalence rates and current views on disease prevention / V.V. Chorna, S.S. Khlestova, N.I. Humeniuk [etc.] Bulletin of Vinnytsia National Medical University. 2020. T. 24(1) S. 158-164. https://doi.org/10.31393/reports-vnmedical-2020-24(1)-31

2. Chorna V.V., Makhniuk V., Gumeniuk N., \& Tomashevskyi A. (2020). Comparative analysis of morbidity indicators among the population of the eu and Ukraine under conditions of stressed load of the Anti-nerrorist operations and psychoprophylaxis measures. Georgian medical al news, 5(302):147-154

3. Chorna V.V. Determination of mental health of the population of Ukraine and EU countries. Environment and health. 2020. № 2(95). C. 47-53(95). https://doi.org/10.32402/dovkil2020.02.047 
4. A strategy for the prevention of chronic diseases in Europe. Focus on community action to promote public health. The vision of the strategy from the standpoint of CINDI electronic resource WHO / Europe. World Health Organization Regional Office for Europe. URL: http://www.euro.who.int/_data/assets/pdf_file/0011/134849/E83057R.pdf

5. 55/2. United Nations Millennium Declaration /Resolution adopted by the General Assembly [without reference to a Mail Committee (A/55/L.2); 8 th plenary meeting, 8 September 2000]. Unted Nations. URL: http:www.un.org/,Millennium Development Goals. Electronic resource (18 September 2000), Millennium Development Goals (MDGs). URL: http://www.un.org/millenniumgoals/index.shtml

6. Analysis of state strategic documents of Ukraine to take into account the Sustainable Development Goals for 2030 adapted for Ukraine: Analytical report. K.: Institute of Socio-Economic Research, 2017, p. 84.

7. Transitional mental health: evaluation results and recommendations for integrating mental health into primary care and community-based platforms in Ukraine. International Medical Corps with the support of the World Bank Group. World Bank Group. documents.worldbank.org> 120767-Ukrainian-PUBLIC-mental-health-UA ipz.org.ua/uploads/2018/01/MH-report-for_INTERNET_All_ua

8. Camille Lassale, G. David Batty, Amaria Baghdaali \& Tasnime Akbaraly. Healthy dietary indices and risk of depressive outcomes: a systematic review and meta-analysis of observational studies. Mol Psychiatry. 2019. 24(7):965-986. doi: https://doi.org/10.1038/s41380-018-0237-8

9. Roger A.H. Adan, Eline M. van der Beek, Jan K. Buitelaar \& Suzanne L. Dickson. Nutritional psychiatry: Towards improving mental health by what you eat. European Neuropsychopharmacology. 2019.29.12.1321-1332. https://doi.org/10.1016/j.evroneuro.2019.10.011

10. Lauren Owen, Bernard Corfe. The role of diet and nutrition on mental health and wellbeing. Proceedings of the Nutrition Society. 2017. 76(4):425-426. doi: https://doi.org/10.1017/SOO29665117001057

11. Morkl S., Wagner-Skacel J., Lahousen T. \& Reininghaus E.Z. The role of nutrition and the gut-brain axis in psychiatry: a review of the literature. Neuropsychobilogy. 2020. 79:80-88. https://doi.org/10.1159/000492834

12. Joseph Firth, Brendon Stubbs, Scott B. Teasdale \& Jerome Sarris. Diet as hot topic in psychiatry: a population-scale study of nutritional intake and inflammatory potential in severe mental illness. World Psychiatry. 2018. 17(3):365-367. doi: https://doi.org/10.1002/wps.20571

13. Moufidath Adjibade, Cedric Lemogne, Chantal Julia \& Emmanuelle Kesse-Guyot. Prospective association between adherence to dietary recommendations and incident depressive symptoms in the French NutriNet-Santé cohort. British Journal of Nutrition. 2018, 120(3):290-300. doi: https://doi.org/10.1017/S0007114518000910

14. Miquel Rosa, Elisabeth Kohls, Margalida Gili \& Brenda W Penninx. Prevention of depression through nutritional strategies in high-risk persons: rationale and design of the MooDFOOD prevention trial. BMC Psychiatry. 2016,16:192. doi: https://doi.org/10.1186/s12888-016-0900-z

15. Wolfgang Marx, Genevieve Moseley, Michael Berk, Felice Jacka. Nutritional psychiatry: the present state of the evidence. Proceedings of the Nutrition Society. 2017. 76(4):427-436. doi: https://doi.org/10.1017/SOO29665117002026

16. Karin Schindler, Sigrid Kosak, Tatjana Schütz \& Michael Hiesmayr. [nutritionDay- an annual cross-sectional audit of nutrition in healthcare]. Ther Umsch. 2014, 71(3):127-33. doi: https://doi.org/10.1024/0040-5930/a000493

17. Rocío Campos del Portillo, Samara Palma Milla, Natalia García Váquez \& Carmen Gómez-Candela . Assessment of nutritional status in the healthcare setting in Spain. Nutr Hosp. 2015 Feb 26;31 Suppl 3:196-208. doi: https://doi.org/10.3305/nh.2015.31.sup3.8767

18. Teresa Valero Gaspar, Jose Manuel Avila Torres, Gregorio Valera-Moreiras. Healthy gastronomy education: challenges and opportunities in the institutional food service. Nutricion Hospitalaria 2018, 35(Spec No4):56-60. Doi: https://doi.org/10.20960/nh.2127

19. Maria Garriga Garcia, Arantza De Las Heras de la Hera. Hospital feeding and healthy gastronomy. Review Nutr Hosp. 2018, 35(Spec No4):140-145. doi: https://doi.org/10.20960/nh.2140

20. Law of Ukraine "On food safety and quality" of 2010 for № 2809-IV. URL: https://www.president.gov.ua/ documents/2809-iv-3236 (accessed 06.09.2005).

21. Resolution of the Cabinet of Ministers of Ukraine "On food standards for persons with tuberculosis and infected with Mycobacterium tuberculosis" (2001 for № 1752. URL: https://zakon.rada.gov.ua/laws/show/1752-2001$\%$ D0\%BF\#Text (accessed 23.11.2012).

22. Order of the Ministry of Health of Ukraine "On improving the organization of medical nutrition and dietary system in Ukraine" from 2013 № 931. URL: https://zakon.rada.gov.ua/laws/show/z2205-13\#Text (accessed 29.10.2013).

23. Imerelli R.E., Kazachinskaya K.P., Moisa B.S. \& Shum S.S. (2016) Rights of persons with mental health problems. Respect for human rights in psychiatric hospitals. Analytical report of the Ukrainian Helsinki Human Rights Union. Ukrainian Helsinki Human Rights Union. K.: KIT, 2016. 34 p.

24. Imerelli R.E., Kazachynska K.P., Moisa B.S., Shum S.S. Rights of persons with mental health problems. Respect for human rights in psychiatric hospitals. Analytical report of the Ukrainian Helsinki Human Rights Union. Ukrainian Helsinki Human Rights Union. K.: KIT, 2016. 34 p.

25. Qingyi Huang, Huan Liu, Katsuhiko Suzuki, Sihui Ma, Chunhong Liu. Linking what we eat to our mood: a review of diet, dietary antioxidants, and depression. Antiioxidants (Basel). 2019,8(9):376. doi: https://doi.org/10.3390/antiox8090376

26. Certificate for the innovation proposal from 16.01.2020. № 3 "Method of determining the personal opinion of the patient's relatives about the payment of medical care in a psychiatric hospital" / Chorna V.V., Makhnyuk V.M., Ocheretyana G.V., Khlestova S.S., Gumeniuk N.I.

27. Jerome Sarris, Alan C. Logan, Nasnime N. Akbaraly \& Felice N. Jacka. Nutritional medicine as mainstream in psychiatry. Review Lancet Psychiatry. 2015. 2(3):271-274. doi: https://doi.org/10.1016/S2215-0366(14)00051-0

28. Jerome Sarris. Nutritional psychiatry: from concept to the clinic. Review Drugs. 2019.79(9):929-934. doi: https://doi.org/10.1007/s40265-019-01134-9

29. Roger A.H. Adan, Eline M. van der Beek, Jan K. Buitelaar \& Suzanne L. Dickson. Nutritional psychiatry: towards improving mental health by what you eat. European Neuropsychopharmacology. 2019. 29(12):1321-1332. doi: https://doi.org/10.1016/j.euroneuro.2019.10.011

30. Aldona Głwacky. PROBLEMATYKA IZASADYŻYWIENIA PACJENTÓW HOSPITALIZOWANYCH W ODDZIAŁACH PSYCHIATRYCZNYCH. KRAKOWSKA AKADEMIA im. Andrzeja Frycza Modrzewskiego. 2018. 38 p.

31. Zakal Yu. On health care in the Republic of Poland // Bulletin of the Association of Psychiatrists of Ukraine. 2011. № 2. URL: http://www.mif-ua.com/archive/article/27208

32. "Law on Mental Health" of the Republic of Poland on August 19, 1994. 